Research Article

\title{
Laryngeal cancer, risk factors, symptoms and treatment
}

\author{
Besim Boçi* and Albana Çuko \\ Otorhynolaryngology-Ophthalmology, University Hospital Center of Tirana, Albania
}

The objective of this study is to identify trends in demographics, symptoms and treatment of laryngeal cancer and to analyze risk factors contributing to the emergence of this cancer. Review of 679 cases with laryngeal cancer diagnosed between the years 2002 and 2011 in ENT SERVICE in University Hospital Center "Mother Teresa". Analysis of these case records addressed demographics, risk factors and treatment for cases according to stage, site and TNM classifications. In all cases, their diagnosis has been confirmed by histopathological studies.

\section{Results}

\section{Epidemiological features}

Prevalence: in 10 years,679 individuals with laryngeal cancer have been reported.

Incidence: in this study incidence is 2.27 per 100.000 inhabitants,meanwhile in the world the incidence is 3.6 per 100,000 inhabitants [1-4].

Distribution by years: From the distribution by years we see it is a 10 year period are diagnosed on average 67.9 cases per year. The year 2011 marks the maximum number of 91 cases, while the lowest number of cases is in 2009 with 52 cases Table 1, Graph 1.

Distribution by age: As seen from the table in the first three decades of life there are no cases diagnosed with laryngeal cancer. It appears in the fourth decade of life, reaching the peak in the 6th decade and then declines [3,4]. Squamous cell carcinomas (SCCs) of the hypopharynx and larynx are uncommon malignancies, usually arising from dysplastic surface epithelium in patients older than 60 years, with the risk factors of smoking and alcohol Table 2, Graph 2 [5] .

Distribution by gender: Of the 679 cases reported, $95.7 \%$ belong to male and only $4.3 \%$ are female. The male/female

Received: 04 April, 2020

Accepted: 21 April, 2020

Published: 23 April, 2020

*Corresponding author: Besim Boçi, Otorhynolaryngology-Ophthalmology, University Hospital Center of Tirana, Albania, Tel: 0035542349209; E-mail: besimboci@hotmail.com ORCID: https://orcid.org/0000-0002-8246-0670 https://www.peertechz.com

\section{Check for updates}

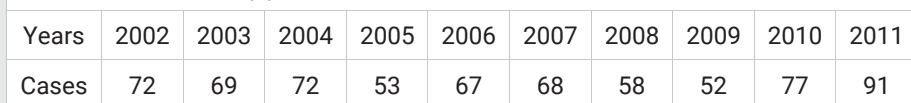

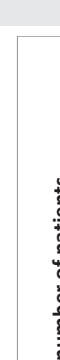

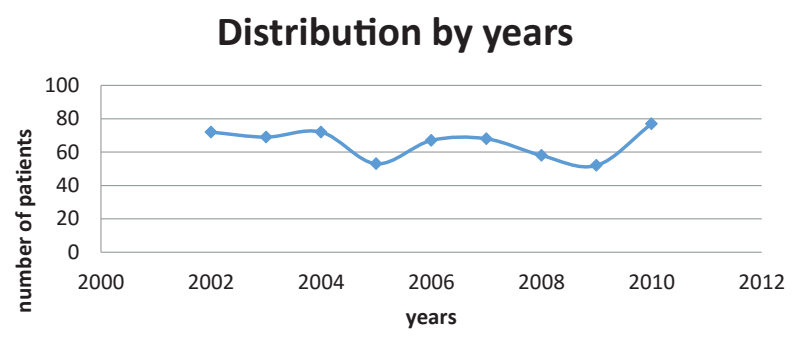

Graph 1: Distribution by years.

Table 2: Distribution by age.

\begin{tabular}{|c|c|c|c|}
\hline $\mathbf{N r}$ & Age & Patients & $\%$ \\
\hline 1 & age $35-45$ & 35 & 5.2 \\
\hline 2 & age $46-55$ & 156 & 23.0 \\
\hline 3 & age 56-65 & 228 & 33.6 \\
\hline 4 & age 66+ & 260 & 38.3 \\
\hline & Total & 679 & 100 \\
\hline
\end{tabular}

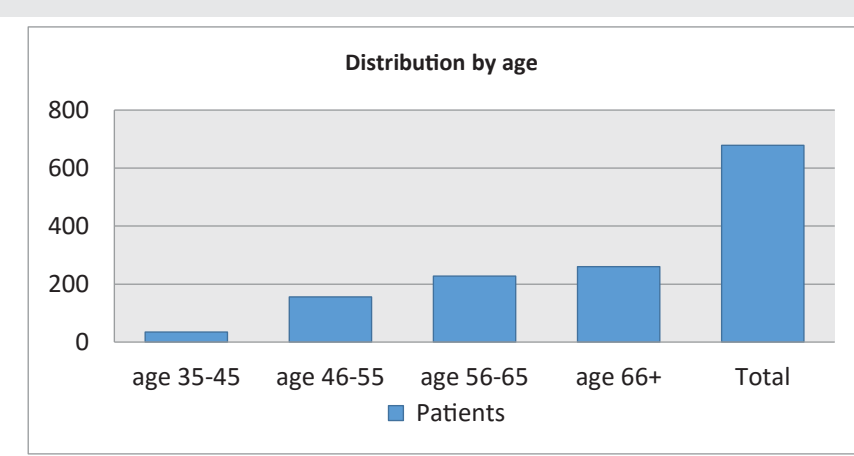

Graph 2: Distribution by age. 
ratio is 22.2: 1. According to Stephenson and Perking this ratio is estimated to be very different ranging from $4: 1$ to $20: 1$ [69].

The British Cancer Research Center reports in 2011, following a detailed study, that in the United Kingdom the percentage of males diagnosed with laryngeal cancer is $82 \%$ and women $18 \%$. So there is a big difference in the distribution of tumor to females in Britain and Albania. This can be explained by the fact that the beginning of smoking in UK women is earlier than ours Table 3, Graph 3.

Distribution village/ town: From the tables we see that those who live in the city are more affected than those living in the village. Village percentage ratio: city is $44.5 \%$ : $55.5 \%$. This report may not be very real, in the context of the major demographic changes that followed the 9os Table 4, Graph 4.

Distribution by profession: We have regrouped professions based on professional exposures, seeking to make a connection between the exposure and the prevalence of the disease Table 5 , Graph $5[10,11]$

Professionals that have contact with gasoline are: driver, tractor, generator, mechanic.

$>$ The professions related to the mineral industry are: miner, geologist etc.

$>$ Employees and others are: teacher, official, officer, economist, mercolog, financier, doctors, agronomist, writer, lawyer and engineer.

> Professions in contact with the wood: carpenter, woodworking, sawdust.

Other workers are: workers, butcher, waiter, sailor, fisherman, barber, tailor, topographer, baker, technician, pastry, shoemaker.

Table 3: Distribution by gender

\begin{tabular}{|c|c|c|}
\hline Gender & Cases & Percentage \\
\hline Male & 650 & $95.7 \%$ \\
\hline Female & 29 & $4.3 \%$ \\
\hline Total & 679 & $100 \%$ \\
\hline
\end{tabular}

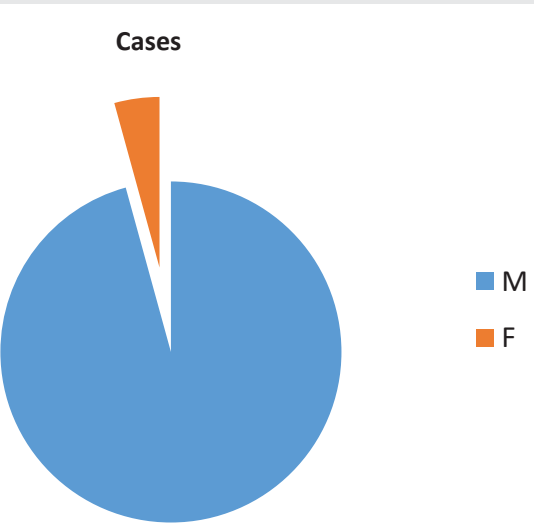

Graph 3: Distribution by gender.
Table 4: Distribution by habitat.

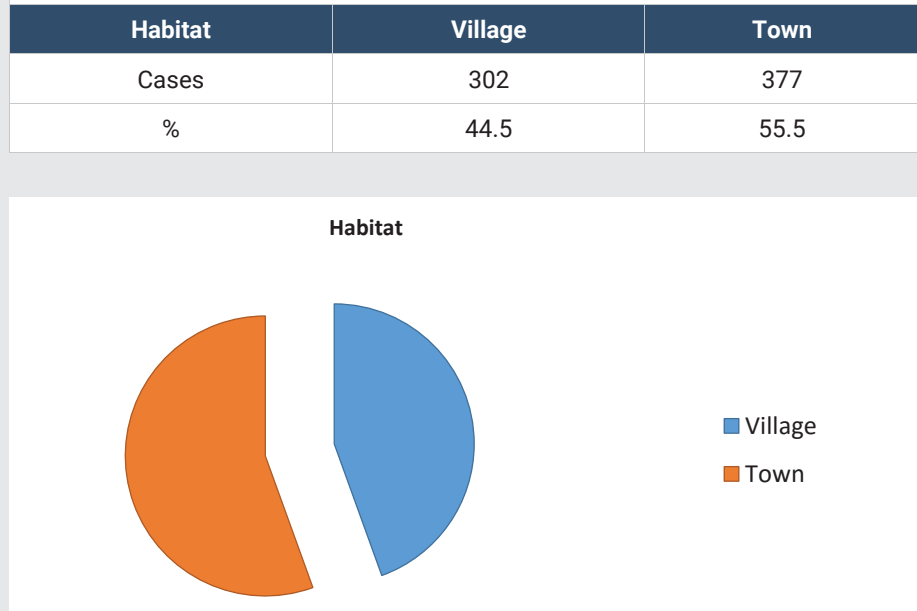

Graph 4: Distribution village/town

Workers working with metals are: copper mill, turntable, electrician, welder.

Occupations exposed to toxic dusts are: masonry, carpenter, baker, farrier.

Workers in agriculture: farmer, coachman

Unclassified

From the above data, there are some interesting conclusions. We see that the highest percentage of those who worked in agriculture and workers. This is to some extent explained by the fact that exposure levels to the risk factors (tobacco, alcohol) of these persons are higher than those of intellectuals that account for $17.5 \%$ of total cases. On the other hand, they are part of low socio-economic levels, which is largely related to malnutrition. An interesting data comes from analyzing the up to a high percentage of professions that are in contact with the fuels we find in the figures of $16.8 \%$. Hydrocarbons are known as potential carcinogenic factors. On the other hand, drivers are a community that consumes significant amounts of tobacco and alcohol, so that potentially carcinogenic effects are gained [10-12]. There are many studies that seek to find a link between occupational exposure and larynx cancer. Some studies by Golgberg, Gustavson or Bofetta also state that even people working in the mineral processing industry or dealing with metal processing are endangered to develop laryngeal cancer. However, in our study there is a link between these professions and this cancer. Professions as drivers, buffers, painters have a not very strong correlation with larynx cancer as quoted by Golgberg and Bofetta [11].

\section{Tumor characteristics}

Histological type: From the table data it seems quite obvious that the epidermoid carcinoma dominated by 99.5 $\%$ and rhabdomiosarcoma type $0.5 \%$. The classification of hitological type of our data is made according to World Health Organization's (WHO) Classification of Head and Neck Tumours Table 6, Graph 6 [5]. 
Table 5: Distribution by professions.

\begin{tabular}{|c|c|c|c|c|c|c|c|c|c|c|c|c|c|}
\hline $\begin{array}{c}\text { Professions by } \\
\text { contact }\end{array}$ & $\begin{array}{c}\text { Professions in } \\
\text { contact with } \\
\text { gasoline }\end{array}$ & official & $\begin{array}{c}\text { Workers in } \\
\text { agriculture }\end{array}$ & $\begin{array}{c}\text { Professions in } \\
\text { contact with the } \\
\text { wood }\end{array}$ & $\begin{array}{c}\text { Other } \\
\text { workers }\end{array}$ & $\begin{array}{c}\text { Worker } \\
\text { working with } \\
\text { metals }\end{array}$ & $\begin{array}{c}\text { Mineral } \\
\text { exposed to toxic } \\
\text { dust }\end{array}$ \\
\hline Cases & 117 & 119 & 186 & 20 & 178 & 23 & 20 \\
\hline$\%$ & 16.8 & 17.5 & 27.3 & 2 & 26.2 & 34 \\
\hline
\end{tabular}

Distribution by professions

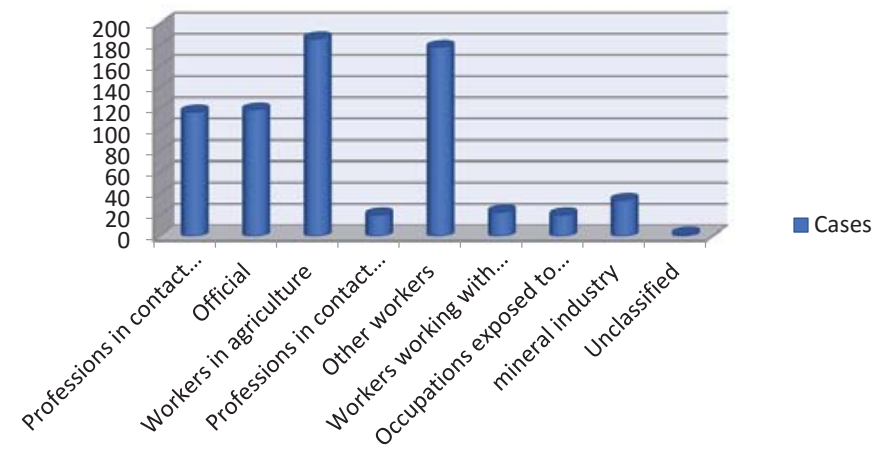

Graph 5: Distribution by professions

Table 6: Histological type.

\begin{tabular}{|c|c|c|}
\hline Type & Epidermoid Carcinoma & Rhabdomiosarcoma \\
\hline Cases & 676 & 3 \\
\hline Percentage \% & 99.5 & 0.5 \\
\hline
\end{tabular}

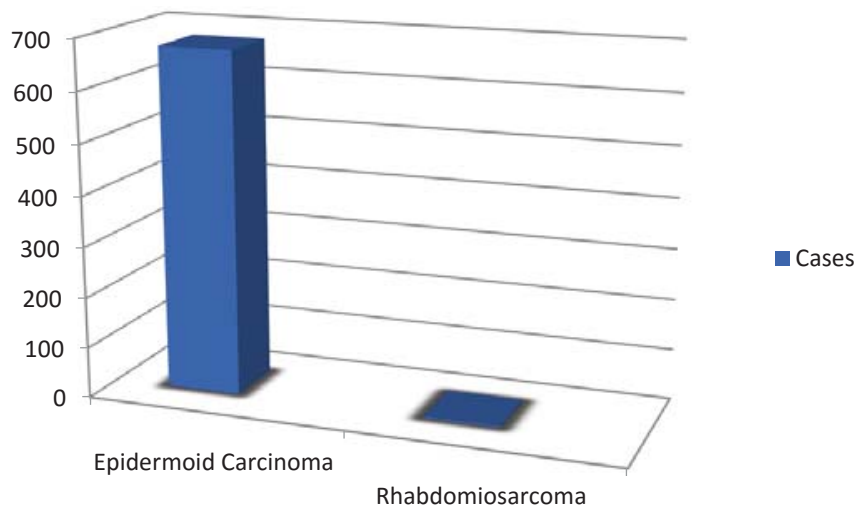

Graph 6: Distribution by histological type.

Tumor localization at the moment of diagnosis: From the above data we see that tumor in glottis region is in $49.5 \%$ of cases, in supraglottic region $36.4 \%$ of cases, in subglottic region $1.6 \%$ and in transglottic region in 5,6\% of cases. In the data postcriciod carcinoma is included in hypopharyngeal inferior carcinoma and marginal tumors are included in supraglottic carcinomas. According to the data presented by the National Institute of Carcinogenic Diseases in USA, 56.1\% of cases with laryngeal cancer are in the glottic region, $32.7 \%$ in the supraglottic region and $1.4 \%$ in the subglottic Table 7 , Graph 7.

\section{Risk factors}

Tobacco: According to international data, the percentage of smokers is $85-95 \%$. Our data are in line with those of literature. According to Talamini, $90 \%$ of the cases affected by laryngeal cancer are smokers Table8 , Graph 8 [12-17].

Alcohol: The major risk factors for SCC of the larynx are long-term tobacco exposure and alcohol abuse and have been long -established $[18,19]$. According to a European study and presented by Talamini, $58 \%$ of cases suffering from laryngeal cancer consume alcohol and $75 \%$ of cases are both tobacco and alcohol consumers. For alcohol consumption these data are not consistent with our study $[10,12,17]$ Table 9, Graph 9.

Other risk factors: These data match Muscat, Wynder, or Zheng's studies that show that there is a connection between laryngeal cancer and various occupational professions related to the textile industry, chemical industries dealing with wood processing $[11,20]$. A small proportion of carcinomas appears to be related to transcriptionally active human papillomavirus infection, prognostic significance of this is not known at these sites [21]. In our 679 cases we don't have data that are connected with HPV as a cause of laryngeal cancer Table 10, Graph 10.

\section{Clinical findings}

The most commonly occurring sign in our patients is dysphonia $(79.8 \%)$ followed by dysphagia (42.5\%), dyspnea $(25.4 \%)$, stridor $(1.62 \%)$ and rarest infestation is fetor, present only in 1 patient. Meanwhile, according to study data Done by Corle Bu Teaching Hospital Accra dysphonia was found in 75.5\% of patients with dysphagia at $29 \%$, dyspnea at $20 \%$, stridor in 10.4 and neck mass at 7.8\% Table 11, Graph 11 [22-24].

\section{Staging. The extent of the tumor at the time of diagnosis}

Staging criteria in Table 12, data collected of cancer staging uses the most recent UICC TNM staging (currently 8th version), which reflects the AJCC cancer staging for all criteria except for T3/T4a subglottic carcinomas. In the AJCC system, T3 carcinomas include those limited to larynx with vocal cord fixation and/ or invasion of paraglottic space and/or inner cortex of the thyroid cartilage. Normal (T1) or impaired (T2) vocal cord mobility and vocal cord fixation (T3) may only be determined clinically.

From the above data we see that in most cases of our cases, the laryngeal cancer is diagnosed in advanced stages III / IV. This proves a low level of early diagnosis of the disease, but also a silent tumor, which it might be diagnosed only when it is spread sufficiently. Perhaps these data point to our AlbanianBalkan character as careless of the disease. According to Jeffrey S.Moyer and Gregory T.Wolf, the third-fourth infiltration is $40 \%-50 \%$, so no great compatibility with our study because of the two factors mentioned above Tables 12,13, Graph 12 [25,26]. 


\section{Treatment}

Surgery: Table 13, Graph 13.

Surgery and its types: From our data we see that patients who undergo surgery are $38.09 \%$. From the above data we see that the type of surgery most commonly used is laryngectomy that in most cases is associated with selective lymph node dissection. In this study striping and mass excision are included in surgery type Cordectomy, which means that we have excised the tumor in stage IIa when the tumor is localized in one vocal fold. The surgery undergo is microlaryngoscopy and excisison of the mass with Kleinsasser laryngeal scissors. Meanwhile no patient has undergone salvage surgery Table 14, Graph 14.

\section{Table 7: Tumor localization.}

\begin{tabular}{|c|c|c|c|c|c|c|}
\hline Localization & Supraglottic & Glottic & Subglottic & $\begin{array}{c}\text { Hypopharyngeal } \\
\text { superior }\end{array}$ & $\begin{array}{c}\text { Hypopharyngeal } \\
\text { inferior }\end{array}$ & Transglottic \\
\hline Cases & 247 & 336 & 11 & 3 & 44 & 38 \\
\hline $\begin{array}{c}\text { Percentage } \\
\%\end{array}$ & 36.4 & 49.5 & 1.6 & 0.4 & 6.5 & 5.6 \\
\hline
\end{tabular}

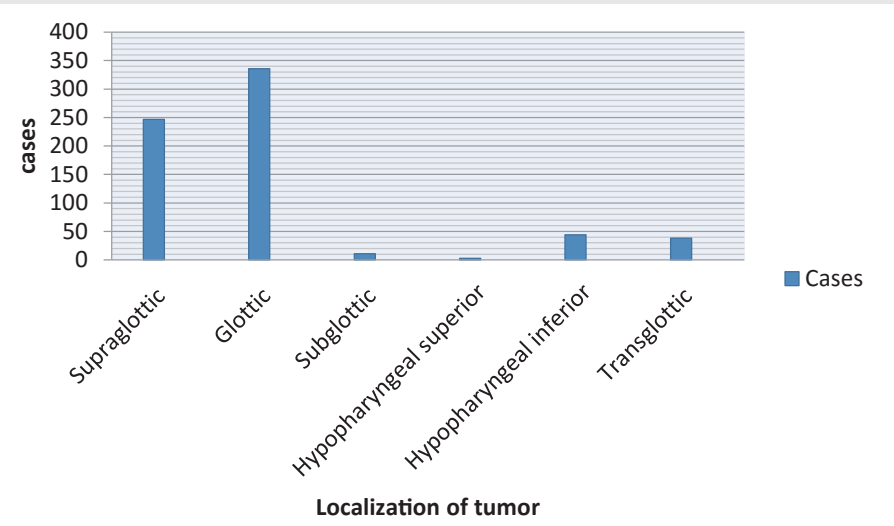

Graph 7: Tumor localization

Table 8: Smoking

\begin{tabular}{|c|c|c|}
\hline Smoking & Yes & No \\
\hline Cases & 630 & 49 \\
\hline$\%$ & $92.8 \%$ & $7.2 \%$. \\
\hline
\end{tabular}

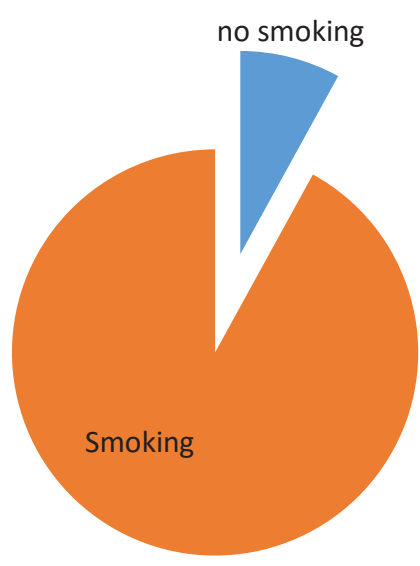

Graph 8: Smoking
Table 9: Alcohol consumption.

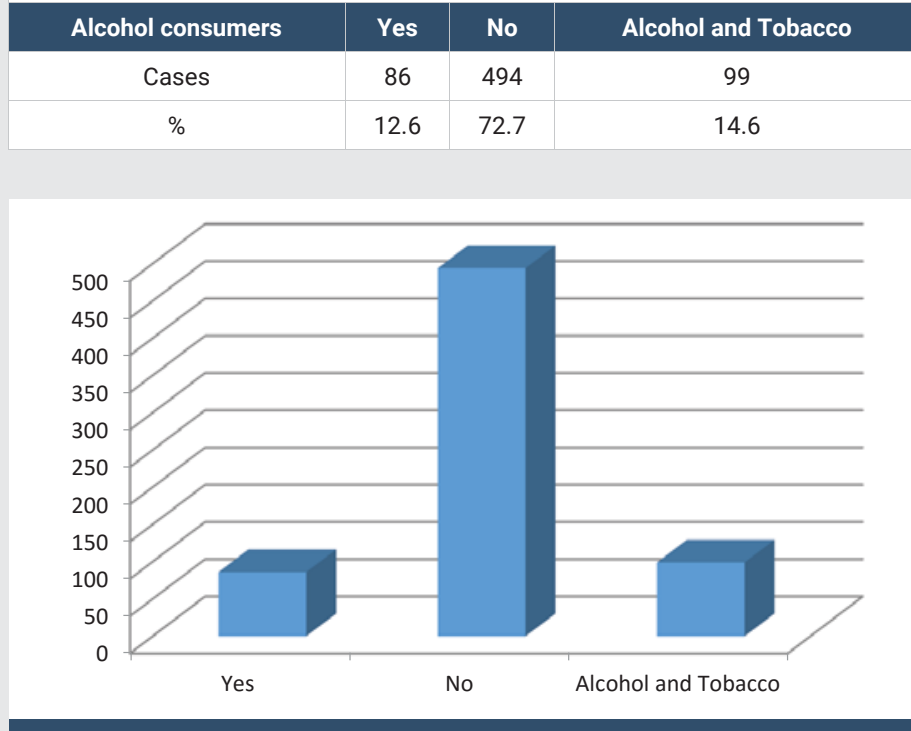

Graph 9: Alcohol consumption

\begin{tabular}{|c|c|c|c|c|c|}
\hline $\begin{array}{l}\text { Other risk } \\
\text { factors }\end{array}$ & $\begin{array}{c}\text { Textile } \\
\text { Industry }\end{array}$ & $\begin{array}{l}\text { Chemical } \\
\text { Industry }\end{array}$ & HPV & $\begin{array}{c}\text { Genetic } \\
\text { predisposition }\end{array}$ & GERD \\
\hline Cases & 2 & 23 & 0 & 5 & 1 \\
\hline$\%$ & 0.29 & 3.3 & 0 & 0.7 & 0.14 \\
\hline
\end{tabular}

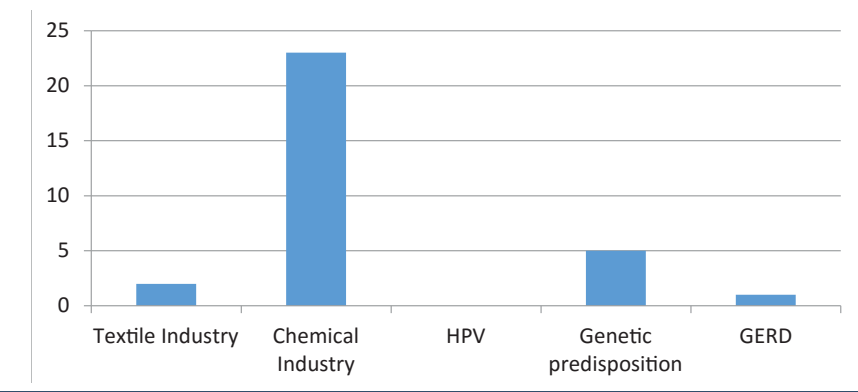

Graph 10: Other risk factors.

Surgery/Radiotherapy/Chemotherapy: of all the data we have for treatment, we see that patients who undergo surgery are $38.09 \%$, while according to Marion and Cartei states that surgery was applied in $55 \%$ of patients. Also radiotherapy according to literature is used in more than $70 \%$ of patients and in our study is used at Table 15, Graph 15, 95\%.

Surgery as a single treatment/ radiotherapy as a single treatment: As we see from the data only $9 \%$ of the patients underwent surgery as a single treatment otherwise $91 \%$ of them underwent radiotherapy as a single treatment. 233 of them underwent total laryngectomy. Those who underwent Cordectomy, Vertical Hemilaryngectomy and Horizontal Supraglottic laryngectomy, it was the only treatment without radiotherapy after surgery Table 16, Graph 16.

Radiotherapy only/Radiochemiotherapy: There are 47 patients who have been treated with chemotherapy. Chemotherapy is used in $4.4 \%$ of cases versus $10 \%$ of literature Table 17, Graph $17[24,27,28]$. 


\section{Discussions}

\section{Tobacco and alcohol}

The importance of smoking exposure in the appearance of laryngeal cancer is a clear case for our study. Also, for alcohol exposure it can be said that there is a clear link. While the relationship between the two factors is commonly our study is not to produce any. The result of the simple fact because it requires more in-depth research $[13,14,16,17]$.

\section{Professions exposed as a result of work in the wood in- dustry, rubber, textile or mineral industries}

As in the literature and in our study there are several cases of laryngeal cancer that have worked in these industries. But despite these we can't judge for the consequent cause connection.

\section{Table 11: Signs and symptoms.}

\begin{tabular}{|c|c|c|c|c|c|c|c|c|}
\hline $\begin{array}{c}\text { Signs and } \\
\text { symptoms }\end{array}$ & Dysphonia & Dysphagia & Dyspnea & Odynophagia & Otalgia & Stridor & $\begin{array}{c}\text { Neck } \\
\text { mass }\end{array}$ & Fetor \\
\hline Cases & 542 & 289 & 173 & 139 & 26 & 11 & 13 & 1 \\
\hline$\%$ & 79.8 & 42.5 & 25.4 & 20.4 & 3.8 & 1.62 & 1.91 & 0.16 \\
\hline
\end{tabular}

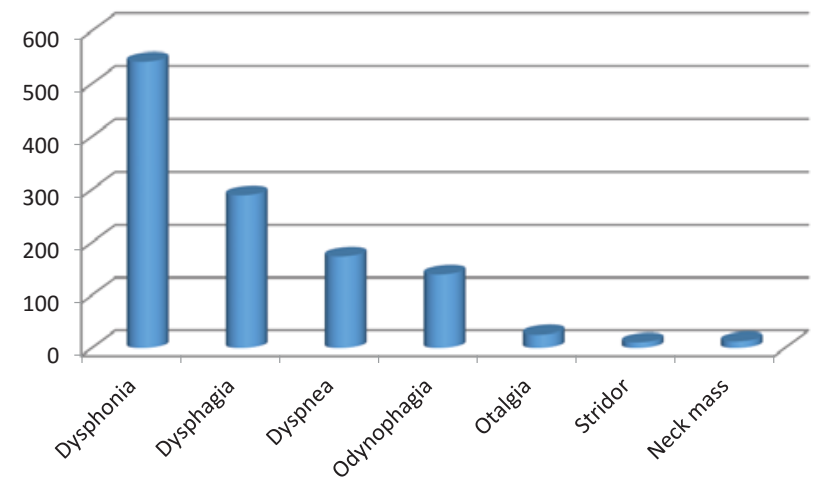

Graph 11: Signs and symptoms.

Table 12: Staging for laryngeal cancer.

\begin{tabular}{|c|c|c|c|c|c|}
\hline Stage & In Situ & I & II & III & IV \\
\hline Cases & 2 & 134 & 58 & 319 & 166 \\
\hline$\%$ & 3 & 19.7 & 8.5 & 47.0 & 24.4 \\
\hline
\end{tabular}

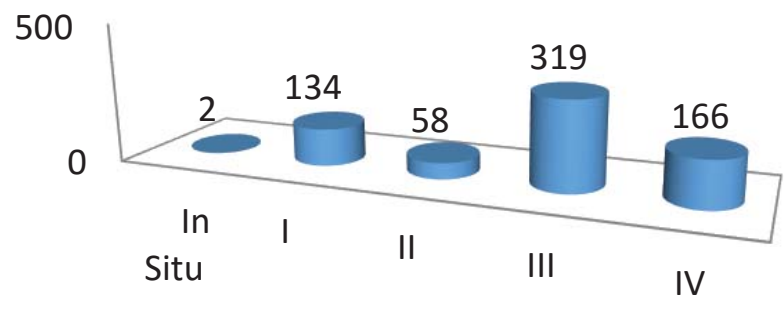

- Cases
Table 13: Patients undergoing surgery or not.

\begin{tabular}{|c|c|c|}
\hline Surgery & Yes & No \\
\hline Cases & 256 & 423 \\
\hline$\%$ & 38.09 & 62.2 \\
\hline Surgery & & \\
\hline & & \\
\hline & & \\
\hline
\end{tabular}

Graph 13: Patients undergoing surgery or not.

Table 14: Surgery and its types.

\begin{tabular}{|c|c|c|c|c|}
\hline Types & $\begin{array}{c}\text { Total } \\
\text { Laryngectomy }\end{array}$ & $\begin{array}{c}\text { Vertical } \\
\text { Hemilaryngectomy }\end{array}$ & $\begin{array}{c}\text { Epiglottectomy or } \\
\text { Cordectomy } \\
\text { Horizontal Supraglottic } \\
\text { Laryngectomy }\end{array}$ \\
\hline Cases & 233 & 17 & 20 & 3 \\
\hline
\end{tabular}

\section{Cases}

Epiglottectomy or Horizontal Supraglottic Laryngectomy

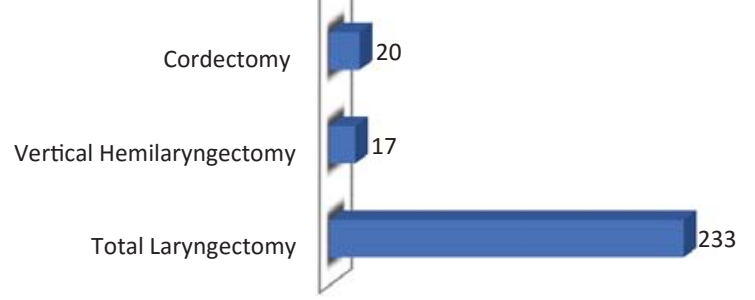

Graph 14: Surgery and its types.

\section{Genetic}

There are some cases that people diagnosed with laryngeal cancer have had close affiliation with this type of cancer, but despite that we are unable to say if there is a real cause connection $[20,29]$.

\section{HPV}

In our study no case has been discovered that has been affected by HPV, but I believe that there has been 'failure to take this factor seriously' or even because this factor has not been detected as a cause.

\section{Plummer-Vinson}

In our study there are several cases with this syndrome but no tangible connection is detected. 


\section{Anemia}

There are some cases of anemia, but this can be explained by the malnutrition or the lack of vitamins that potentially are the cause of laryngeal cancer [29-64].

\section{Conclusions}

Laryngeal cancer occurs with an incidence of 2.27 cases per 10,000 inhabitants and an average of 67.9 new cases per year. Incidence for male is 4.36 per 100.000 inhabitants, for female is 0.19 per 100.000 inhabitants.The incidence is low according to the changes that occurred in Albania in the 1990s, a large part of the Albanians had the opportunity to move abroad and be treated elsewhere.Also many cases can be treated in private hospitals, which further reduce the incidence.

Table 15: Surgery/Radiotherapy before surgery.

\begin{tabular}{|c|c|c|}
\hline Treatment & Surgery & Radiotherapy before Surgery \\
\hline Cases & 273 & 383 \\
\hline
\end{tabular}

$\square$ Surgery $\square$ Radiotherapy before Surgery

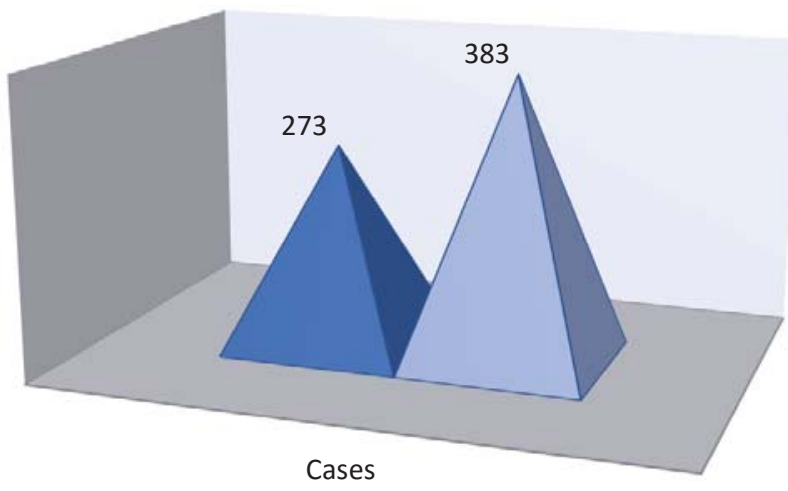

Graph 15: Surgery/Radiotherapy before surgery.

Table 16: Surgery only/ Radiotherapy only.

\begin{tabular}{|c|c|c|}
\hline Treatment & Surgery only & Radiotherapy only \\
\hline Cases & 40 & 359 \\
\hline
\end{tabular}

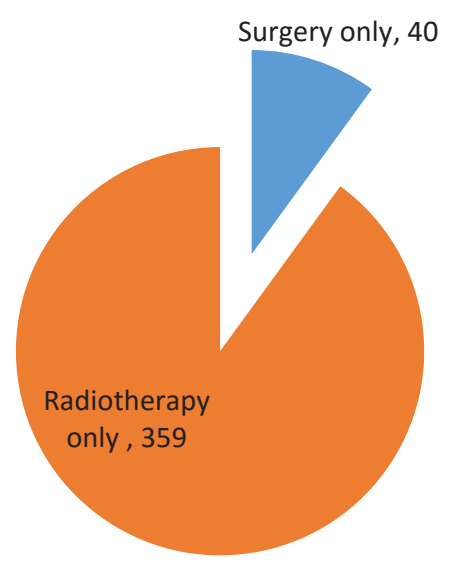

Graph 16: Surgery only/ Radiotherapy only.
Table 17: Radiotherapy only/ Radiochemiotherapy

\begin{tabular}{|c|c|c|}
\hline Treatment & Radiotherapy only & Radiochemiotherapy \\
\hline Cases & 359 & 47 \\
\hline
\end{tabular}

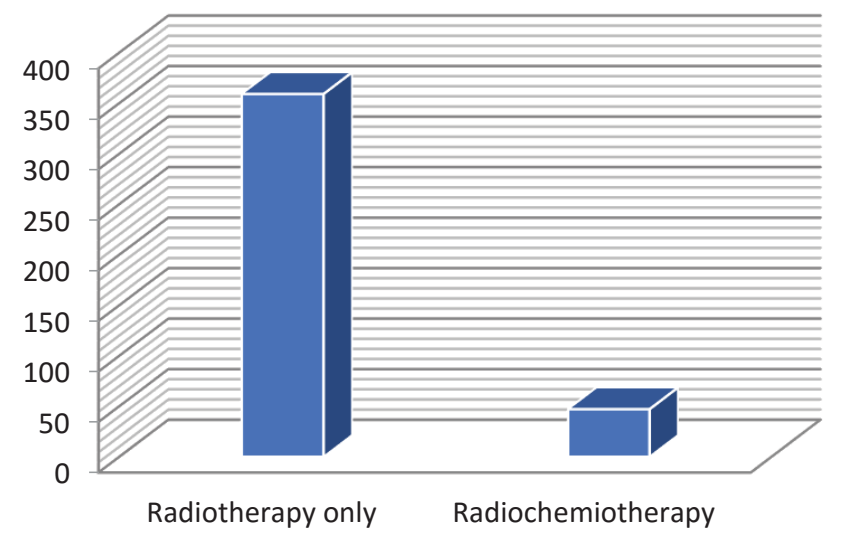

Graph 17: Radiotherapy only/ Radiochemiotherapy.

In our study, we find more cases in the city than in the village.In our study $55.5 \%$ of the individuals were living in urban zones while $44.5 \%$ were living in rural zones. Because of the change of the regime in Albania, an internal migration occurred after the 1990s, many villagers were settled in the city and so we have no accurate result of the percentage of individuals living in the city and those living in the village for the occurrence of laryngeal cancer.Male to female ratio is 95.7 $\% / 4.3 \%$.

In the four first decades of life are recorded cases, while the age with the largest number of people affected is more than 66 years old ( $38.3 \%$ ). In the first 30 years of life, we find no cases. The largest number of people affected is $60-70$ years old.

About $92.8 \%$ of cases are consumers of tobacco, while 14.6 $\%$ of cases consume alcohol and tobacco both .It is found a link between tobacco and alcohol and the years of exposure to these two factors. Also there are cases affected by cancer of the larynx that work in mineral industry, wood processing, textiles and industries that have exposure to toxic dust. From this study, 319 of the cases ( $47 \%)$ at the time of diagnosis are in the third stage, $24.4 \%$ in the fourth stage, $19.7 \%$ in the first stage, $8.5 \%$ at the second stage. Dysphonia is the most common clinical finding in most of cases, followed by dysphagia. The most affected region is glottis 336 cases $(49.5 \%)$ followed by supraglottic region 247 cases $(36.4 \%)$. In total treatment 40 pacients underwent surgery only ( cordectomy,Vertical Hemilaryngectomy and Horizontal Supraglottic laryngectomy ).The most common treatment modality was radiotherapy as single treatment 359 cases ( $52,8 \%$ ). Surgery in total 273 (37.7\%) cases; Radiochemotherapy 47 (6.9\%) cases.

In addition, we found that there is a link between exposure to wood, dust, or metal working in appearance of the laryngeal cancer. It is a task to detect the quantitative relationship between exposure years and this cancer. Also, the work should be deepened in HPV as a potential causative factor.In Albania 
we see laryngeal cancer exclusively in smokers and alcohol abusers. We think that as a very important risk factor except smoking is a traditional Albanian alcoholic drink called "Raki". We conclude from our study that the incidence in women is lower compared to men because smoking is still taboo in Albania. Since primary prevention is not fully feasible then we need to focus more on secondary prevention or early psychology by coordinating activity between family practitioners and those specialists.

\section{References}

1. Jemal A, Siegel R, Ward E, Murray $T, X u$ J, et al. (2007) Cancer statistics. CA Cancer J Clin 57: 43-66. Link: https://bit.ly/2RX5LAm

2. Plevneshi A Dissertation: epidemiological and anatomic-clinic correlations on laryngeal cancer in ENT service of Mother Teresa Hospital in the years 19801990. 9-12.

3. Flanders WD, Rothman KJ (1982) Occupational risk for laryngeal cancer. Am J Public Health 72: 369. Link: https://bit.ly/2VvYhGV

4. World Health Organisation (WHO) (1985) Smoking and Its Effects on Health WHO technical report,seriesno.568. WHO, Geneva.

5. Georgopulos NA,Sykiotis GP,Sgourou A, Papachatzopoulou A, Markou KB et al. (2003) Autonomously functioning thyroid nodules in a former iodinedeficient area commonly harbor gain-of-function mutations in the thyrotropin signaling pathway. Eur J Endocrinol 149: 287-292. Link: https://bit.ly/2RUjmlv

6. Flint PW, Haughey BH, Lund VJ, Niparko JK, Robbins TK, et al. (2015) Cummings Otolaryngology: Head and Neck Surgery. Link: https://bit.ly/3bskVFn

7. Cummings Ch (1987) Otolaryngology-Head and Neck Surgery

8. Ballenger JJ (2005) Diseases of the Nose. Throat, Ear, Head and Neck 685739.

9. Mayers EM (1991) Head and Neck Oncology. 281-297.

10. Trell E, Korsgaard R, Hood B, Kitzing P, Nordén G, et al. (1976) Aryl Hydrocarbon Hydroxylase Inducibility and Laryngeal Carcinomas. Lancet 2: 140. Link: https://bit.ly/2VLdC56

11. Loury MC,Johns ME, Danes BS (1987) In Vitro Hyperdiploidy in Head and Neck CancerA Genetic Predisposition?. Arch Otolaryngol Head and Neck Surg 113 1230-1233. Link: https://bit.ly/2KpV5W

12. Rothman KJ (1999) The proportion of cancer attributable to alcohol consumption. Prev Med 9: 174-179. Link: https://bit.ly/3aqbkNZ

13. Moore C (1971) Cigarette Smoking and Cancer of the Mouth, Pharynx, and LarynxA Continuing Study. JAMA 218: 553-558. Link: https://bit.ly/2KoCtGH

14. Kalin HA (1966) The Dorn study of smoking and mortality among U.S. veterans: report on eight and one-half years of observation. Natl Cancer Inst Monogr 19: 1-125. Link: https://bit.ly/2xOg0QF

15. Blot WJ, McLaughlin JK, Winn DM, Austin DF, Greenberg RS, et al (1988) Smoking and drinking in relation to oral and pharyngeal cancer. Cancer Res 48: 3282-3287. Link: https://bit.ly/3eFXvyh

16. Menvielle G, Luce D, Goldberg P, Bugel I, Leclerc A (2004) Smoking, alcoho drinking and cancer risk for various sites of the larynx and hypopharynx a case-control study in France. Eur J Cancer Prev 13: 165-172. Link: https://bit.ly/3buUgbd

17. Stevens J (1979) Synergistic Effect of Alcohol on Epidermoid Carcinogenesis in the Larynx. Otolaryngol Head and Neck Surgery 87: 751. Link: https://bit.ly/3cEK1RO
18. Feldt-Rasmussen U (2001) lodine and cancer. Thyroid 11: 483-486. Link https://bit.ly/3boi4xj

19. Torrente MC, Rodrigo JP, Haigentz M, Dikkers FG, Rinaldo A, et al. (2011) Human papillomavirus infections in laryngeal cancer. Head Neck 33: 581-586. Link: https://bit.ly/2RY46dK

20. SchantzSP (1993) Carcinogenesis, markers, staging, and prognosis of head and neck cancer. Curr Opin Oncol 5: 483-490. Link: https://bit.ly/2VSp92u

21. Union for International Cancer Control (UICC) (2017) In: Brierley JD, Gospodarowicz MK, Wittekind C, eds. TNM Classifcation of Malignant Tumours. $8^{\text {th }}$ ed. New York: Wiley-Blackwell.

22. KirchnerJA, CarterD (1987) Intralaryngeal barriers to the spread of cancer Acta Otolaryngol 103: 503-513. Link: https://bit.ly/3eKI2xg

23. Mitta IB, Marks JE, Ogura JH (1984) Transglotic carcinoma.Cancer 53: 151 161.Link: https://bit.ly/3eGQFZz

24. Piquet JJ, Chevalier D (1991) Subtotal laryngectomy with crico-hyoidoepiglottopexy for the treatment of extended glottic carcinomas .Am J Surg 162: 357361. Link: https://bit.ly/3cBiAlw

25. Carter RL (1998) Pathology of squamous carcinoma soft he head and neck. Curr Opin Oncol 5: 491.

26. Dolcetti R, Doglioni C, Maestro R, Gasparotto D, Barzan L, et al. (1996) p53 over-expression is an early event in the development of human squamous-cel carcinoma of the larynx: Genetic and prognostic implications. Int J Cancer 52 178-182. Link: https://bit.ly/3cGw6uC

27. Harrison LB, Solomon B, Miller S, Fass DE, Armstrong J, et al. (1990) Prospective computer-assisted voice analysis for patients with early stage glottic cancer: A preliminary report of the functional result of laryngeal irradiation. IntJ Radiat Oncol Biol Phys 19: 123-127. Link: https://bit.ly/2XRv6zz

28. Mayers EN, Wagner RL, Johnson JT (1994) Microlaryngoscopic Surgery for T1 Glottic Lesions: A Cost-Effective Option. Ann Otol Rhinol Laryngol 103: 28-30. Link: https://bit.ly/3bok2Od

29. Roels H (1992) Histopathology of laryngeal tumors. Acta Otorhinolaryngol Belg 46: 127

30. Plevneshi A (1996) Dissertation: epidemiological and anatomic-clinic correlations on laryngeal cancer in ENT service of Mother Teresa Hospital in the years 1980-1990.

31. Boyle P, Macfarlane GJ, Zheng T, Maisonneuve P, Evstifeeva T, et a. (1997) Recent advances in epidemiology of head and neck cancer. Curr Opin Oncol 4 471-477. Link: https://bit.ly/34X5en6

32. Hautant A (1930) Ma technique de l'hemilaryngectomie, ses resultants Otorhinolaryngollnt 5: 217

33. Yuen A, Medina JE, Goepfert H, Fletcher G (1984) Management of stage T3 and T4 glottic carcinomas. Am J Surg 148: 467-472. Link: https://bit.ly/2yANMZy

34. Coates HL, DeSanto LW, Devine KD, Elveback LR (1986) Carcinoma of the supraglottic larynx. A review of 221 cases. Arch Otolaryngol 102: 686-689. Link: https://bit.ly/3bwpqic

35. Mc Gavran MH, BauerWC, OguraJH (1971) The incidence of cervical lymph node metastases from epidermoid carcinoma of the larynx and their relationship to certain characteristics of the primary tumor. Cancer. 14: 55

36. Kirchner JA, Cornog JL, Holmes RE (1974) Transglottic cancer. Its growth and spread with in the larynx. Arch Otolaryngol 99: 247-251. Link: https://bit.ly/2VNGeL5

37. Kazem I, vanden Broek P (1984) Planned preoperative radiation therapy vs definitive radiotherapy for advanced laryngeal carcinoma. Laryngoscope 94 1355-1358. Link: https://bit.ly/2VsUjic 
38. Esteban F, Moreno JA, Delgado-Rodriguez M, Mochon A (1993) Risk factors involved in stomal recurrence following laryngectomy. J Laryngol Otol 107 527-531. Link: https://bit.ly/34WeLuS

39. Griebe MS, Adams GL (1987) "Emergency" laryngectomy and stomal recurrence. Laryngoscope 97: 1020-1024. Link: https://bit.ly/3eDSzdj

40. Schneider JJ, Fletcher GH, Burkley HT (1975) Control by irradiation alone of nonfixed clinically positive lymph nodes from squamous cell carcinoma of the oral cavity, oropharynx, supraglottic larynx, and hypopharynx. AJR Am Roentgenol 123: 42-48. Link: https://bit.ly/3eGtQFu

41. KennedyJJ, KrauseCJ (1997) The Importance of Tumor Attachment to the Carotid Artery. Arch Otolaryngol 103: 70-73. Link: https://bit.ly/2RUmRyD

42. Martin M, Gehanno P, Depondt J (1994) A Phase II Study of Induction Carboplatin and 5-fluorouracil before locoregional treatment versus locoregional treatment alone in head and neck carcinomas. Proc Am Soc Clin Oncol 1994; 13:906.

43. Fu KK, Eisenberg L, Dedo HH, Phillips TL (1977) Results of integrated management of supraglottic carcinoma. Cancer 40: 2874-2881. Link: https://bit.ly/3btwoVn

44. Lindberg R (1972) Distribution of cervical lymph node metastases from squamous cell carcinoma of the upper respiratory and digestive tracts. Cancer 29: 1446. Link: https://bit.ly/34WffRR

45. Lee NK, Goepfert H, Wendt CD (1990) Supraglottic laryngectomy for intermediate-stage cancer: U.T. M.D. Anderson Cancer Center experience with combined therapy. Laryngoscope 100: 831-836. Link: https://bit.ly/34Vq3PX

46. Soo KC, Shah JP, Gerold FP, Gopinath SK, Jaques DP, et al. (1988) Analysis of prognostic variables and results after supraglottic partial laryngectomy. Am J Surg 156: 301-305. Link: https://bit.ly/2RTvz0c

47. Coates HL, DeSanto LW, Devine KD, Elveback LR (1976) Carcinoma of the supraglottic larynx. A review of 221 cases. Arch Otolaryngol 102: 686-689. Link: https://bit.ly/2Vr56cq

48. Nadol JB (1981) Treatment of carcinoma of the epiglottis. Ann Otol Rhinol Laryngol 90: 442. Link: https://bit.ly/2RWYvEt

49. ShahJP, AndersonPE (1994) The impact of patterns of nodal metastasis on modifications of neck dissection. Ann Surg Oncol 1: 521-532. Link https://bit.ly/34Vy0EM

50. RiceDH, WetmoreSJ, Singer M (1991) Recurrent squamous cell carcinoma of the true vocal cord. Head Neck 13: 549- 552. Link: https://bit.ly/2XXvsEG

51. Boles R, Komorn R (1969) Carcinoma of the laryngeal glottis: A fiveyear review at a university hospital. Laryngoscope 79: 909-920. Link: https://bit.ly/3eHGvrC

52. Soto Ortega I, Suarez Nieto C, Fresno Forcelledo MF, Escudero Gomis J (1987) Lymph node response and its relationship to prognosis in carcinomas of the head and neck. Clin Otolaryngol Allied Sci 12: 241-247. Link: https://bit.ly/2xOnbZ6

53. CarrBI (1986) Cancer in Bangladesh: a model for some problems and proposed solutions in the Third World. Cancer Detect Prev 9: 195-202. Link: https://bit.ly/2zmc6yT

54. Flanders WD, Rothman KJ (1982) Occupational risk for laryngeal cancer. Am J Public Health 72: 369-372. Link: https://bit.ly/3cHvrZP

55. Klayman MB (1968) Exposureto insecticides. Arch Otolaryngol Head Neck Surg 88: 116
56. Moss E (1976) Oral and Pharyngeal cancer in textile workers. Ann NY Acad Sci 271: 301-307. Link: https://bit.ly/2VtOSiV

57. Stall PM, McGillT (1971) Exposure to asbestoss and laryngeal carcinoma. J Laryngol Otol 89: 513.

58. Arthur K, Farr HW (1972) Prognostic significance of histologic grade in epidermoid carcinoma of the mouth and pharynx. Am J Surg 124: 489-492. Link: https://bit.ly/2XVyqK3

59. Mcgavran MH, Bauer WC, Ogura JH (1961) The incidence of cervica lymph node metastases from epidermoid carcinoma of the larynx and their relationship to certain characteristics of the primary tumor. A study based on the clinical and pathological findings for 96 patients treated by primary en bloc laryngectomy and radical neck dissection. Cancer 14: 55-56. Link: https://bit.ly/34ZjLyL

60. Meyer-Breiting E, von Ilberg C (1979) Spread and mode of metastasis of supraglottic laryngeal carcinoma. ORLJ Otolaryngol Relat Spec 41: 288-300. Link: https://bit.ly/2yAIOXS

61. Biller HF, Davis WH, Ogura JH (1998) Delayed contralateral cervical metastases with laryngeal and laryngopharyngeal cancer. Laryngoscope 81 1499-1502. Link: https://bit.ly/34Z78UC

62. El-Naggar AK, Chan JKC, Grandis JR, Takata T, Slootweg PJ (2017) WHO Classification of Head and Neck Tumours. $4^{\text {th }}$ ed. Lyon, France: IARC 2017. World Health Organization Classification of Tumours 9. Link: https://bit.ly/3elzh6v

63. Amin MB, Edge S, Grenne FL, Byrd DR, Brookland RK, et al. (2017) The Eighth Edition AJCC Cancer Staging Manual: Continuing to build a bridge from a population-based to a more "personalized" approach to cancer staging. CA Cancer J Clin 67: 93-99. Link: https://bit.ly/3btid2z

\section{Discover a bigger Impact and Visibility of your article publication with}

\section{Peertechz Publications}

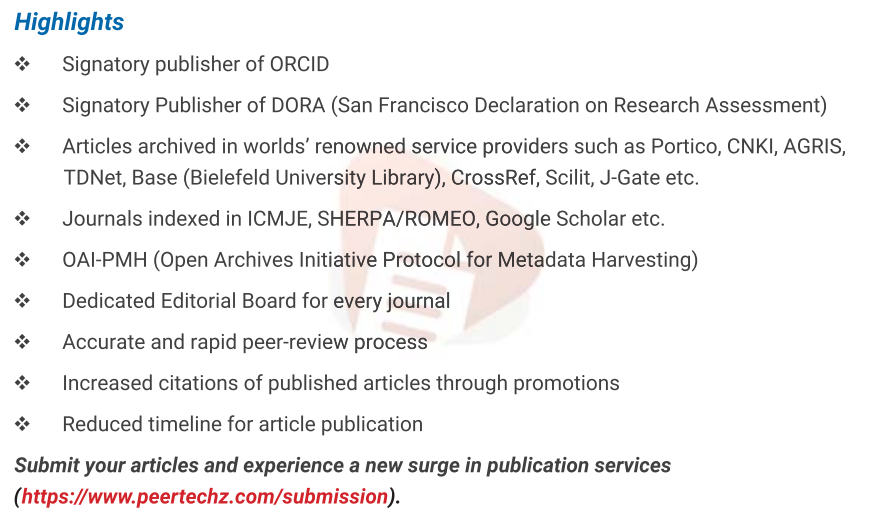

Peertechz journals wishes everlasting success in your every endeavours.

Copyright: ๑ 2020 Boçi B, et al. This is an open-access article distributed under the terms of the Creative Commons Attribution License, which permits unrestricted use, distribution, and reproduction in any medium, provided the original author and source are credited. 